\title{
ANALISIS PERSEPSI PETANI PETERNAK TERHADAP PERAN PENYULUHAN DALAM PENGEMBANGAN AGRIBISNIS PETERNAKAN BABI DI DESA GIWAN KECAMATAN TIOM KABUPATEN LANNY JAYA
}

\author{
Elinde Yoman, M. T. Massie, R. E. M. F. Osak* , J. Pandey*
}

Fakultas Peternakan Universitas Sam Ratulangi, Manado 95115.

\begin{abstract}
ABSTRAK
Penelitian ini bertujuan untuk mengetahui persepsi petani peternak terhadap peran penyuluh pertanian dalam pengembangan agribisnis ternak babi bagi kelompok peternak babi di Desa Giwan Kecamatan Tiom Kabupaten Lanny Jaya. Penelitian menggunakan metode survei dengan penentuan kelompok sampel ditentukan secara sengaja (purposive sampling). Hasil penelitian menunjukkan bahwa : Peternak babi di desa Giwan sebagian besar sudah memiliki persepsi baik terhadap penyuluh dalam perannya sebagai pendidik (80\%), sebagai konsultan (75\%), sebagai motivator $(75 \%)$ dan sebagai organisator $(80 \%)$ terhadap peternak babi di desa Giwan. Kesimpulan : Sebagian besar peternak babi di desa Giwan memiliki persepsi baik terhadap penyuluh dalam perannya sebagai pendidik, motivator, dan sebagai organisator terhadap peternak dalam mengelola usaha ternak babi.
\end{abstract}

Kata Kunci: Agribisnis, Ternak Babi, Penyuluh, Giwan.

\section{ABSTRACT}

\begin{abstract}
ANALYSIS OF FARMERS' PERCEPTIONS TOWARD THE ROLE OF COUNSELING IN THE DEVELOPMENT OF PIG FARMING ON AGRIBUSINESS IN GIWAN VILLAGE, TIOM DISTRICT, LANNY JAYA REGENCY. The objective of this study was to determine farmer's percep
\end{abstract}

*Korespondensi(corresponding author) Email: Richard_osak@yahoo.com tons toward the role of agricultural extension agents in the development of pig livestock agribusiness for breeder's in Giwan Village, Tiom District, Lanny Jaya Regency. This study used a survey method. Sample of group breeder wasdetermined by purposive sampling and sample of breeders was selected by simple random sampling method. The results of the study showed that: (1) Most pig farmers in Giwan village had good or high perceptions of extension workers in their roles as educators (80\%), still have moderate as consultants (75\%), as motivators $(75 \%)$, and as organizers $(80 \%)$ of farmers in providing counseling in Giwan village. The conclusion of this research was farmers in Giwan village have good perceptions of extension workers in their roles as educators, motivators, and as organizers of farmers in managing pigs' business.

Keywords: Agribusiness, Pig Farm,

Extension, Giwan.

\section{PENDAHULUAN}

Pembangunan peternakan termasuk peningkatan kinerja agribisnis peternak tradisional, banyak dipengaruhi oleh intervensi pihak luar seperti pemerintah daerah termasuk para penyuluh pertanian lapangan. Peran penyuluh merupakan keterlibatan seseorang untuk melakukan komunikasi informasi secara sadar dengan 
tujuan membantu sasarannya memberikan pendapat sehingga dapat membuat keputusan yang benar.

Mosher (1997) menguraikan tentang peran penyuluh pertanian, yaitu: sebagai guru, penganalisa, penasehat, sebagai organisator, sebagai pengembang kebutuhan perubahan, penggerak perubahan, dan pemantap hubungan masyarakat petani. Permentan Nomor: 273/Kpts/OT.160/4/2007, menyebutkan ada tiga arah pengembangan kelompok tani, yaitu: (1) Peningkatan kemampuan kelompok tani dalam melaksanakan fungsinya (wadah belajar, wahana kerjasama dan unit produksi); (2) Peningkatan kemampuan para anggota dalam mengembangkan agribisnis; dan (3) Menguatkan kelompok tani menjadi organisasi petani yang kuat dan mandiri.

Keberhasilan suatu penyuluhan sangat dipengaruhi oleh besarnya peran penyuluh yang diberikan melalui kegiatan penyuluhan, sebagaimana dikemukakan Fashihullisan (2009) bahwa peranan penyuluhan dalam pemberdayaan masyarakat dapat dikategorikan ke dalam 4 (empat) hal yaitu sebagai fasilitator, pendidik, utusan/wakil dan sebagai teknisi. Pembinaan kelembagaan petani perlu dilakukan secara berkesinambungan, diarahkan pada perubahan pola pikir petani dalam menerapkan sistem agribisnis, serta menurut Osak et al. (2018) dan Manese et al. (2016) bahwa perlunya penerapan teknologi berbasis pada sistem pertanian ramah lingkungan.

Pembinaan kelembagaan petani juga diarahkan untuk menumbuhkembangkan kelompok tani (poktan) dan gabungan kelompok tani (gapoktan) dalam menjalankan fungsinya, serta meningkatkan kapasitas poktan dan gapoktan melalui pengembangan kerjasama dalam bentuk jejaring dan kemitraan (Kementan, 2013).

Upaya pengembangan agribisnis bagi kelompok peternak sangat membutuhkan kemampuan penyuluh dalam memainkan perannya sesuai arah kebijakan pengembangan kelompok tani. Dengan kata lain, dapat dikatakan bahwa tinggi rendahnya tingkat perkembangan kelompok tani sangat dipengaruhi oleh besarnya peran penyuluh yang diberikan dalam melakukan pengembangan terhadap kelompok tani.

Kecamatan Tiom Kabupaten Lanny Jaya Provinsi Papua pada tahun 2014 memiliki populasi ternak sapi sebanyak 225 ekor, kambing sebanyak 112 ekor, babi sebanyak 3.752 ekor, kelinci sebanyak 1.024 ekor dan ayam kampung sebanyak 2.987 ekor (BPS, 2014). Desa Giwan merupakan salah satu desa yang terletak di Kecamatan Tiom memiliki 
kelompok tani peternak dan berdasarkan pengamatan lapangan diketahui bahwa kelompok tani memiliki aktivitas agribisnis khususnya sub sistem agribisnis budidaya ternak babi.

Berdasarkan latar belakang tersebut, maka perlu untuk mengkaji tentang persepsi petani terhadap peran penyuluh dalam upaya pengembangan kelompok tani di Desa Giwan ini. Rumusan masalah penelitian ini, yaitu :1) Bagaimana karakteristik peternak babi di Desa Giwan Kecamatan Tiom Kabupaten Lanny Jaya; dan 2) Bagaimana persepsi peternak terhadap peran penyuluh pertanian dalam pengembangan agribisnis ternak babi bagi kelompok peternak babi di Desa Giwan Kecamatan Tiom Kabupaten Lanny Jaya.

\section{METODE PENELITIAN}

Penelitian ini dilaksanakan bertempat di Desa Giwan Kecamatan Tiom Kabupaten Lanny Jaya. Penentuan lokasi penelitian berdasarkan pada desa yang memiliki jumlah kelompok tani paling banyak. Penelitian dilakukan selama dua (2) bulan, yaitu pada bulan Januari dan Februari 2018.

Penelitian ini menggunakan metode survei menurut Sugiyono (2009), di mana dilakukan pendekatan secara langsung kepada kelompok tani dan melakukan wawancara untuk mengisi kuesioner, sekaligus melakukan pengamatan di lapangan. Penentuan kelompok tani sampel ditentukan secara sengaja (purposive sampling), dengan pertimbangan yaitu: (1) anggota kelompok tani memiliki ternak babi terbanyak, dipilih 20 peternak babi; dan (2) anggota aktif kelompok tani, sehingga mengetahui dan memiliki pandangan individu terhadap terhadap peran penyuluh. Definisi operasional variabel yang diukur :

a) Karakteristik peternak babi responden dalam penelitian ini, yaitu : (1) Kepemilikan ternak babi peternak; (2) Umur peternak; (3) Pendidikan peternak; dan (4) Pengalaman beternak.

b) Persepsi adalah pandangan individu terhadap suatu objek (stimulus), yaitu terhadap peran penyuluh. Peran penyuluh pertanian yaitu:

i. Peran penyuluh pertanian sebagai pendidik adalah penyuluh harus terampil menyampaikan inovasi untuk mengubah perilaku sasarannya.

ii. Peran penyuluh pertanian sebagai analisator adalah seorang penyuluh harus memiliki keahlian untuk melakukan pengamatan terhadap keadaan, masalah dan kebutuhan masyarakat sasaran serta mampu memecahkan masalah petani. 
iii. Peran penyuluh pertanian sebagai konsultan adalah seorang penyuluh harus ketrampilan dan keahlian untuk memilih alternative perubahan yang paling tepat, yang secara teknis dapat dilaksanakan, secara ekonomis menguntungkan dan dapat diterima oleh nilai-nilai budaya sosial setempat.

iv. Peran penyuluh pertanian sebagai organisator adalah seorang penyuluh harus mempunyai ketrampilan dan keahlian untuk menjalin hubungan baik dengan segenap lapisan masyarakat, mampu menumbuhkan kesadaran dan menggerakkan partisipasi masyarakat, mampu berinisiatif terciptanya perubahan-perubahan.

Analisis data dilakukan dengan menggunakan analisis deskriptif. Metode deskriptif dapat diartikan sebagai prosedur pemecahan masalah yang diselidiki dengan menggambarkan atau mendeskripsikan keadaan subjek/objek penelitian berdasarkan fakta-fakta yang tampak atau sebagaimana adanya (Nawawi, 1995). Analisis deskriptif dilakukan untuk menggambarkan karakteristik agribisnis petani peternak babi dan persepsi petani peternak terhadap peran penyuluh pertanian dalam pengembangan agribisnis ternak babi bagi kelompok peternak babi di Desa Giwan Kecamatan Tiom Kabupaten Lanny Jaya.

\section{HASIL DAN PEMBAHASAN}

\section{Karakteristik Peternak Babi di Desa Giwan}

Karakteristik petani peternak babi di desa Giwan yaitu bagian dari pribadi dan melekat pada diri seseorang peternak. Karakteristik ini mendasari tingkah laku seseorang peternak dalam menjalankan agribisnis ternak babi di Desa Giwan Kecamatan Tiom Kabupaten Lanny Jaya. Karakteristik peternak babi responden Desa Giwan, yaitu :

\section{Kepemilikan Ternak Babi di Desa Giwan}

Umumnya usaha ternak babi di Desa Giwan masih tradisional, sehingga kepemilikan ternak juga masih skal kecil.Kepemilikan ternak babi di desa Giwan dapat dilihat pada Tabel 1.

Tabel 1 menunjukkan jumlah ternak babi yang dipelihara rata-rata4,1 ekor dengan rentang kepemilikan antara 26 ekor, di mana sebagian besar ternak babi yang dipelihara yaitu sebanyak 54,88\% berjenis kelamin jantan, sedangkan sejumlah $45,12 \%$ berjenis kelamin betina.Hasilpenelitian menunjukkan bahwa sebagianbesar peternak memiliki skala kepemilikan ternak babi skala kecil, karena keterbatasan ketersediaan pakan ternak babi. 
Tabel 1. Kepemilikan Ternak Babi Peternak Responden

\begin{tabular}{cccc}
\hline No & Uraian & Jumlah (ekor) & $\begin{array}{c}\text { Persentase } \\
(\%)\end{array}$ \\
\hline 1. & Jantan & 45 & 54,88 \\
2. & Betina & 37 & 45,12 \\
\hline & Jumlah & 82 & 100 \\
& Rata-rata & 4,1 & \\
\hline
\end{tabular}

Jenis ternak babi yang dipelihara peternak di desa Giwan, yaitu babi lokal dan hasil persilangan babi Bali yang pernah didatangkan oleh seorang peternak pada tahun 1990-an.

Beberapa permasalahan yang dihadapi oleh peternak babi Desa Giwan dalam mengembangkan usaha ternak babi di antaranya faktor pakan. Pemberian pakan pada ternak babi baik kualitas maupun kuantitasnya belum memenuhi kebutuhan hidup pokok ternak babi. Jenis pakan yang diberikan pada ternak babi di Desa Giwan umumnya berupa umbi dan hijauan (daun dan tangkai) ubijalar. Usman et al. (2016) mengemukakan bahwa varietas ubi jalar di Papua untuk bahan pangan dibudidayakan dengan cara khusus, serta memiliki kadar pati tinggi dan rasa manis, sementara varietas denganrasa umbi kurang enak dan kandungan seratnya tinggi, serta umbi yang kecil atau rusak digunakan untuk pakan babi. Ubijalar merupakan makanan pokok terutama bagi masyarakat Papua, disamping itu saat ini sudah mulai menggunakan makanan nasi dari beras. Untuk menghindari terjadinya persaingan antara kebutuhan manusia, maka pengembangan ubi jalar dibedakan antara bahan pangan manusia dan pakan babi (Usman, et al., 2016).

\section{Umur Responden.}

Umur merupakan faktor yang mempengaruhi terhadap kemampuan kerja seorang petani peternak, karena kemampuan kerja seorang petani sangat dipengaruhi oleh tingkat umur petani tersebut. Karakteristik peternak babi responden Desa Giwan berdasarkan umur dapat dilihat pada Tabel 2.

Tabel 2 menggambarkan karakteristik petani peternak berdasarkan umur petani di desa Giwan. Peternak berusia antara 20-55 tahun dengan presentase sebesar 95\% sehingga sebagian besar peternak babi Desa Giwan kategori kelompok umur produktif. 
Tabel 2. Karakteristik Responden Berdasarkan Umur

\begin{tabular}{lccc}
\hline No & $\begin{array}{c}\text { Kategori Responden Berdasarkan Umur } \\
\text { (Tahun) }\end{array}$ & Jumlah (orang) & $\begin{array}{c}\text { Persentase } \\
(\%)\end{array}$ \\
\hline 1. & $<20$ & - & 0 \\
2. & $20-55$ & 19 & 95 \\
3. & $>55$ & 1 & 5 \\
\hline & Jumlah (n) & 20 & 100 \\
\hline
\end{tabular}

Kategori kelompok umur dapat mempengaruhi kinerja peternak dalam mengelola agribisnis ternak babi, terkait adanya inovasi, seseorang pada umur nonproduktif akan cenderung sulit menerima inovasi.

Hal ini menunjukkan bahwa usia mempengaruhi kemampuan individu di dalam mengembangkan potensi dirinya dalam belajar. Tingkat umur memberikan pengaruh terhadap kapasitas dan kemampuan belajar seseorang. Seorang yang relatif muda dan masih produktif akan memiliki tingkat kecepatan yang lebih baik di dalam belajar dibandingkan dengan seorang yang sudah lanjut usia atau masih sangat kanak-kanak.

\section{Pendidikan Peternak}

Tinggi rendahnya pendidikan petani akan mempengaruhi caradan pola berfikir dalam pengembangan adopsi suatu inovasi. Tingkat pendidikan petani semakin tinggi maka semakin cermat dan mudah dalam memecahkan masalah usahataninya akan cenderung terbuka untuk mencoba suatu inovasi.
Karakteristik peternak babi responden Desa Giwan berdasarkan tingkat pendidikan formal dapat dilihat pada Tabel 3 yang menunjukkan tingkat pendidikan dari peternak babi responden di Desa Giwan sebagian besar berpendidikan SMP (75\%), kemudian berpendidikan SMA/SMK sebanyak $15 \%$ dan SD sebanyak $10 \%$. Artinya bahwa tingkat pendidikan di desa Giwan masih tergolong relatif rendah, hal ini disebabkan oleh ketidak-mampuan masyarakat untuk melanjutkan pendidikannya hingga jenjang pendidikan yang lebih tinggi.

Rendahnya tingkat pendidikan mempengaruhi peternak dalam menerima materi penyuluhan dengan tingkat pendidikan yang umumnya relatif masih rendah, sehingga sulit untuk adopsi dan menerapkan pengetahuan agribisnis beternak dengan lebih cepat/baik. 
Tabel 3. Karakteristik Responden Berdasakan Pendidikan

\begin{tabular}{llcc}
\hline No & $\begin{array}{c}\text { Kategori Responden Berdasarkan } \\
\text { Tingkat Pendidikan }\end{array}$ & Jumlah (orang) & $\begin{array}{c}\text { Persentase } \\
(\%)\end{array}$ \\
\hline 1. SD & 2 & 10 \\
2. SMP & 15 & 75 \\
3. SMA/SMK & 3 & 15 \\
4. & $>$ SMA/SMK & - & - \\
\hline \multicolumn{2}{r}{ Jumlah (n) } & 20 & 100 \\
\hline
\end{tabular}

Sebagian besar peternak babi Desa Giwan berpendidikan SMP sehingga perlu peran penyuluh lapangan, yang diharapkan cukup menunjang kinerja agribisnis ternak babi di Desa Giwan. Jika peternak babi Desa Giwan dapat mengadopsi materi ilmu pengetahuan dan teknologi yang diberikan penyuluh lapangan, diharapkan meningkatkan kenerja usaha agibisnis ternak babi Desa Giwan.

Tingkat pendidikan peternak cenderung mempengaruhi cara berpikir dan tingkat penerimaan mereka terhadap inovasi dan teknologi baru. Peternak yang tingkat pendidikannya lebih tinggi seharusnya dapat meningkatkan pendapatan peternak yang lebih besar (Indrayani dan Andri, 2018). Tingkat pendidikan dari petani peternak juga menentukan keberhasilan agribisnis peternakan karena dengan berbekal pengetahuan yang cukup melalui jenjang pendidikan, maka akan turut mempengaruhi produktivitas usaha peternakan sehingga peran sumberdaya manusia dalam pembangunan peternakan merupakan unsur yang sangat penting.

\section{Pengalaman Beternak}

Pengalaman beternak adalah lamanya seseorang berkecimpung dalam usaha ternak itu, yang mempunyai pengalaman lebih lama cenderung lebih cepat dalam pengambilan keputusan karena pengalaman dapat dijadikan pedoman dalam melakukan usahanya (Suranjaya, et al., 2017). Selanjutnya dikatakan bahwa pengalaman beternak babi cukup lama dapat menyebabkan responden dapat menjalankan usahanya dengan baik. Karakteristik peternak berdasarkan pengalaman agribisnis ternak babi dapat dilihat pada Tabel 4 yang menunjukkan pengalaman beternak babi di Desa Giom sebagian besar (70\%) sudah sekitar 20-30 tahun. 
Tabel 4. Karakteristik Responden Berdasakan Pengalaman Beternak

\begin{tabular}{llccc}
\hline No & & Lama Usaha & Jumlah (orang) & Persentase (\%) \\
\hline 1. & $<20$ Tahun & 5 & 25 \\
2. & 20-30 Tahun & 14 & 70 \\
3. & $>30$ Tahun & 1 & 5 \\
\hline & & Jumlah (n) & 20 & 100 \\
\hline
\end{tabular}

Hal ini menunjukkan bahwa tingkat pengalaman beternak responden dapat dikatakan cukup, tetapi belum dapat disimpulkan peternak menguasai dan mengikuti perkembangan teknologi dalam pengelolaan usaha ternak. Peternak di Desa Giwan umumnya masih memiliki pengalaman beternak babi secara tradisional, baik sistem budidaya maupun sistem agribisnis ternak babi yang dilaksanakan.

Pengalaman merupakan suatu proses sikap, perilaku, sertakemampuan seseorang dalam melakukan aktivitas tertentu (Sampurna et al., 2011). Pengalaman beragribisnis ternak babi merupakan jumlah tahun lamanya peternak bekerja di bidang peternakan babi. Peternak babi yang sudah lama beternak akan lebih mudah untuk menerapkan inovasi dibanding pada peternak pemula, hal ini dikarenakan pengalaman yang lebih banyak sehingga sudah dapat membuat perbandingan dalam mengambil keputusan.

\section{Persepsi Peternak Babi terhadap Penyuluhan Agribisnis Peternakan}

Persepsi menurut Sudarsono dan Suharsono (2016) dan Sunaryo (2004) adalah merupakan salah satu faktor yang membentuk sebuah kesadaran pada diri seseorang, dan merupakan proses akhir dari pengamatan yang diawali oleh proses pengindraan, yaitu proses diterimanya stimulus oleh alat indra, lalu diteruskan ke otak, dan baru kemudian individu menyadari tentang sesuatu yang dipersepsikan.

Persepsi peternak babi dalam penelitian ini yaitu pandangan peternak terhadap suatu objek (stimulus) yaitu penyuluh pertanian lapangan, khususnya peran penyuluhan peternakan terhadap peternak babi desa Giwan.Peran penyuluh pertanian dalam penelitian ini sesuai Mosher (1997), yaitu sebagai pendidik, konsultan, motivator/analisator dan organisator. 
Tabel 5.Persepsi Peternak Babi di Desa Giwan terhadap Penyuluh Pertanian

\begin{tabular}{|c|c|c|c|c|c|}
\hline \multirow{2}{*}{ No } & \multirow{2}{*}{$\begin{array}{l}\text { Indikator Persepsi Peternak } \\
\text { terhadap Penyuluh }\end{array}$} & \multicolumn{4}{|c|}{ Jumlah Peternak (orang) } \\
\hline & & $\mathrm{R}$ & $\mathrm{S}$ & $\mathrm{T}$ & TS \\
\hline \multirow[t]{2}{*}{1.} & Peran penyuluh pertanian sebagaipendidik & - & 4 & 16 & - \\
\hline & Prosentase $(\%)$ & - & 20 & 80 & - \\
\hline \multirow[t]{2}{*}{2.} & Peran penyuluh pertanian sebagai konsultan & 3 & 15 & 1 & 1 \\
\hline & Prosentase $(\%)$ & 15 & 75 & 5 & 5 \\
\hline \multirow[t]{2}{*}{3.} & Peran penyuluh pertanian sebagai motivator & 2 & 3 & 15 & - \\
\hline & Prosentase $(\%)$ & 10 & 15 & 75 & - \\
\hline \multirow[t]{2}{*}{4.} & Peran penyuluh pertanian sebagai organisator & - & 1 & 16 & 3 \\
\hline & Prosentase $(\%)$ & & 5 & 80 & 15 \\
\hline
\end{tabular}

Keterangan : $\mathrm{R}=$ Rendah; $\mathrm{S}$ = Sedang; $\mathrm{T}$ = Tinggi; dan TS = Tinggi Sekali

Peran penyuluh pertanian dalam penelitian ini dapat dilihat pada Tabel 5, yang menjelaskan jumlah peternak yang memiliki persepsi sedang (S) terhadap peran penyuluh pertanian sebagai pendidik dalam memberi penyuluhan berjumlah 4 peternak (20\%), sedangkan yang memiliki persepsi tinggi sebanyak 16 peternak (80\%). Hal ini menunjukkan bahwa sebagian besar peternak babi di desa Giwan memiliki persepsi baik terhadap penyuluh dalam perannya sebagai pendidik dalam memberikan penyuluhan.

Peran penyuluh pertanian sebagai konsultan dalam memberi penyuluhan, menunjukkan sebagian besar atau 15 peternak (75\%) yang memiliki persepsi sedang (S) dan terdapat 3 peternak (15\%) memiki persepsi rendah (R) terhadap penyuluh sebagai konsultan, dan hanya 1 peternak (5\%) memiliki persepsi tinggi (T) dan juga 1 peternak (5\%) memiliki persepsi sangat tinggi (ST) terhadap penyuluh sebagai konsultan. Hal ini menunjukkan bahwa sebagian besar peternak babi di desa Giwan masih memiliki persepsi sedang dan rendah terhadap penyuluh dalam perannya sebagai konsultan terhadap peternak dalam memberikan penyuluhan.

Peran penyuluh pertanian sebagai motivator bahkan sebagai analisator dalam memberi penyuluhan, sebagian besar peternak atau berjumlah 16 peternak (80\%) sudah memiki persepsi tinggi (T) bahkan terdapat 4 peternak (20\%) memiliki persepsi sangat tinggi (TS) terhadap penyuluh sebagai organisator, sedangkan peternak yang memiliki persepsi sedang (S) hanya sebanyak 1 peternak $(5 \%)$ dan bahkan tidak ada sama sekali peternak yang memiliki persepsi rendah terhadap penyuluh sebagai motivator. Hal ini menunjukkan bahwa sebagian besar peternak babi di desa Giwan sudah memiliki persepsi baik (tinggi) terhadap penyuluh dalam perannya sebagai motivator terhadap peternak dalam 
memberikan penyuluhan. Muhammad et al. (2014) mengatakan bahwa lama usaha berhubungan sangat nyata dengan persepsi peternak mengenai pengembangan usaha peternakan. Persepsi peternak merupakan tanggapan para peternak terhadap objek, yang dilihat dari tingkat pengetahuan peternak, penilaian peternak dan minat peternak terhadap manfaat suatu inovasi bagi mereka (Umam et al, 2012).

Peran penyuluh pertanian sebagai organisator dalam memberi penyuluhan, sebagian besar peternak atau berjumlah 16 peternak (80\%) sudah memiki persepsi tinggi (T) bahkan terdapat 3 peternak (15\%) memiliki persepsi sangat tinggi (TS) terhadap penyuluh sebagai organisator, sedangkan peternak yang memiliki persepsi sedang (S) hanya sebanyak 1 peternak (5\%) dan bahkan tidak ada sama sekali peternak yang memiliki persepsi rendah terhadap penyuluh sebagai organisator.

Hasil ini menunjukkan bahwa sebagian besar peternak babi di desa Giwan sudah memiliki persepsi baik (tinggi) terhadap penyuluh dalam perannya sebagai organisator terhadap peternak dalam memberikan penyuluhan. Hasil ini sama dengan Talibo, et al. (2017) bahwa persepsi petani peternak terhadap peran penyuluh di kecamatan Sangkub sebagian besar peternak menilai baik dan bahkan ada $6,67 \%$ peternak menilai sangat baik.

\section{KESIMPULAN DAN SARAN}

\section{Kesimpulan}

Peternak babi di desa Giwan sebagian besar sudah memiliki persepsi baik atau tinggi terhadap penyuluh dalam perannya sebagai pendidik dalam memberikan penyuluhan agribisnis ternak babi. Peternak babi di desa Giwan sebagian besar masih memiliki persepsi sedang terhadap penyuluh dalam perannya sebagai konsultan terhadap peternak dalam memberikan penyuluhan agribisnis ternak babi. Sebagian besar peternak babi di desa Giwan sudah memiliki persepsi baik terhadap penyuluh dalam perannya sebagai motivator terhadap peternak dalam memberikan penyuluhan. Sebagian besar peternak babi sudah memiliki persepsi baik terhadap penyuluh dalam perannya sebagai organisator terhadap peternak dalam memberikan penyuluhan di desa Giwan Kecamatan Tiom Kabupaten Lanny Jaya.

\section{Saran}

Pemerintah atau dinas pertanian setempat masih perlu meningkatkan peran penyuluh sebagai pendidik, konsultan, motivator dan organisator terhadap peternak babi untuk meningkatkan agribisnis ternak babi dalam menunjang pendapatan rumahtangga di desa Giwan 
dan di daerah Kecamatan Tiom Kabupaten Lanny Jaya.

\section{DAFTAR PUSTAKA}

Abdullah, A. dan H. Ibrahim, 2014. Persepsi peternak terhadap kinerja penyuluh dalam pengembangan teknologi pengolahan jerami padi dan limbah ternak sapi potong. Jitro 1(1):100-107.

BPS, 2014. Lanny Jaya Dalam Angka 2014. BPS Kabupaten Lanny Jaya.

Fashihullisan, M. 2009. Penyuluhan Pertanian: Peranan Penyuluhan Dalam Pembangunan. http://fashihullisantugaspenyuluhan .blogspot.com/2009/12/perananpenyuluhan-dalampembangunan.html Diakses tanggal.23 November 2017.

Indrayani, I. dan Andri, 2018.Faktor-faktor yang mempengaruhi pendapatan usaha ternak sapi potong di Kecamatan Sitiung, Kabupaten Dharmasraya. Jurnal Peternakan Indonesia 20(3):151-159.

Kementan, 2013. Peraturan Menteri Pertanian Nomor 82/Permentan/OT.140/ 8/2013 Tentang Pedoman Pembinaan Kelompok Tani Dan Gabungan Kelompok Tani. Kementerian Pertanian, Jakarta.

Manese, M.A.V., R.E.M.F. Osak dan A.A. Sajouw, 2016. Penerapan ecofinancial analysis untuk pengembangan peternakan di pedesaan yang berkelanjutan. Prosiding Seminar Nasional "Pembangunan Pedesaan Berkelanjutan Berbasis Peternakan di Indonesia”, P: 65-70.
Mosher, A.T., 1997. Menggerakkan dan Membangun Pertanian. Yasa Guna, Jakarta.

Muhammad, S.D.S., R.A.J. Legrans, E. Wantasen dan J. Lainawa, 2014. Hubungan antara faktor sosial ekonomi dengan persepsi peternak terhadap pengembangan peternakan sapi perah di Kota Tomohon. Jurnal Zootek 34(2):39-48

Nawawi, H. 2005. Manajemen Sumber Daya Manusia, Untuk Bisnis Yang Kompetitif. Gajah Mada University Press, Yogyakarta.

Osak, R.E.M.F., T.F.D. Lumy and M.L. Rundengan, 2018. Application of environmentally friendly technology to dairy farming in South Tomohon Subdistrict, North Sulawesi, Indonesia. International Journal of Engineering Inventions 7(4):16-18.

Sampurna, I.P., I.K. Suatha, dan Z. Menia, 2011. Pola pertumbuhan dimensi panjang dan lingkar tubuh babi landrace. Majalah Ilmiah Peternakan 14(1):18-21.

Sudarsono, A., dan Yudi Suharsono, 2016 Hubungan persepsi terhadap kesehatan dengan kesadaran (mindfulness) menyetor sampah anggota klinik asuransi sampah di Indonesia. Jurnal Ilmiah Psikologi Terapan 4(1):31-52.

Sunaryo, 2004. Psikologi Untuk Keperawatan. EGC, Jakarta.

Suranjaya, I.G., M. Dewantari, I.K.W. Parimartha, dan I.W. Sukanata, 2017. Profile usaha peternakan babi skala kecil Di Desa Puhu Kecamatan Payangan Kabupaten 
Gianyar. Majalah Ilmiah Peternakan 20(2):79-83.

Talibo, R., B. F. J. Sondakh, A. A. Sajow dan J. Lainawa, 2017. Analisis persepsi petani peternak sapi potong terhadap peran penyuluh di Kecamatan Sangkub Kabupaten Bolaang Mongondow Utara. Jurnal Zootek 37(2) : 513-525.

Umam, K., N. Kusrini dan D. Kurniati, 2012. Hubungan antara karakteristik dengan persepsi peternak terhadap inseminasi buatan pada sapi potong di
Kelurahan Tuan-Tuan Kecamatan

Benua Kayong Kabupaten

Ketapang. Jurnal Sosial Ekonomi Pertanian 1(3): 23-28.

Usman., B.M.W Tiro, S. Tirajoh dan Bustami, 2016. Profil kelompok dan kinerja reproduksi ternak babi lokal pada kelompok tani Doligame Distrik Tiom, Kabupaten Lanny Jaya, Papua. http://repository.pertanian. go.id/bitstream/handle/123456789 $16856 /$ sosek $\% 2041$.pdf?sequence $=$ 1 \&isAllowed=y 